\title{
First record of the Northern Ecuadorian Shrew, Cryptotis niausa Moreno Cárdenas \& Albuja, 2014 (Eulipotyphla, Soricidae), in Colombia
}

\author{
Ingrith Yuliany Mejía-Fontecha ${ }^{1,2}$, Daniela Velásquez-Guarín ${ }^{1,2}$, Karol Dangeli Pérez Tapie ${ }^{3}$, \\ Paula A. Ossa-López ${ }^{1}$, Fredy A. Rivera-Páez ${ }^{1}$, Héctor E. Ramírez-Chaves ${ }^{1,2 *}$ \\ 1 Grupo de Investigación en Genética, Biodiversidad y Manejo de Ecosistemas, Departamento de Ciencias Biológicas, Facultad de Ciencias \\ Exactas y Naturales, Universidad de Caldas, Manizales, Caldas, Colombia •IYMF: ingrith1896@gmail.com_@ 1 ttps://orcid.org/0000-0003- \\ 2438-3029 • DVG: daniela.bio202830@gmail.com (1) https://orcid.org/0000-0002-6487-7608•PAOL: paula.ossa@ucaldas.edu.co (1) https:// \\ orcid.org/0000-0002-9079-4988•FARP: fredy.rivera@ucaldas.edu.co (1) https://orcid.org/0000-0001-8048-5818・HERC: hector.ramirez@ \\ ucaldas.edu.co (1 https://orcid.org/0000-0002-2454-9482 \\ 2 Centro de Museos, Museo de Historia Natural, Universidad de Caldas, Manizales, Caldas, Colombia \\ 3 Semillero de Investigación en Plantas y afines PHYTOS; Programa de Biología, Facultad de Ciencias Exactas y Naturales, Universidad de \\ Caldas, Manizales, Caldas, Colombia・KDPT: karol.1711517190@ucaldas.edu.co \\ * Corresponding author
}

\begin{abstract}
In Colombia, seven species of small-eared shrews of the genus Cryptotis Pomel, 1848 have been reported, and five of them endemic to the country. Here, we present the first confirmed record from Colombia of Cryptotis niausa Moreno Cárdenas \& Albuja, 2014, a species that was previously known from only nine localities in Ecuador. The Colombian record comes from the Departamento de Nariño, in extreme southwestern Colombia, and it is supported by morphology and cytochrome- $b$ gene evidence. This record increases to eight the number of species of Cryptotis from Colombia.
\end{abstract}

\section{Keywords}

Andes, biodiversity, cytochrome- $b$, Ecuador, endemic, morphology, Neotropics

Academic editor: William Tavares | Received 6 May 2021 | Accepted 17 September 2021 | Published 27 September 2021

Citation: Mejía-Fontecha IY, Velásquez-Guarín D, Pérez Tapie KD, Ossa-López PA, Rivera-Páez FA, Ramírez-Chaves HE (2021) First record of the Northern Ecuadorian Shrew, Cryptotis niausa Moreno Cárdenas \& Albuja, 2014 (Eulipotyphla, Soricidae), in Colombia. Check List 17 (5): $1345-1352$. https://doi.org/10.15560/17.5.1345

\section{Introduction}

The recognized diversity of small-eared shrews of genus Cryptotis Pomel, 1848 (Eulipotyphla, Soricidae) in South America has increased in the last 30 years, with the description of at least 10 of the 17 currently recognized species (Noguera-Urbano et al. 2019). Colombia holds the highest diversity (seven species; Noguera-Urbano et al.
2019), followed by Venezuela (six species; Quiroga-Carmona and DoNascimiento 2016), Ecuador (four species; Moreno Cárdenas and Albuja 2014; Zeballos et al. 2018), and Peru (three species; Moreno Cárdenas and Albuja 2014; Zeballos et al. 2018). In Ecuador, three species of Cryptotis are endemic to the country: the Ecuadorian 
Small-eared Shrew, Cryptotis equatoris (O. Thomas, 1912), the Northern Ecuadorian Small-eared Shrew, C. niausa Moreno Cárdenas \& Albuja, 2014, and the Osgood's Small-eared Shrew Cryptotis osgoodi (Stone, 1914) (Moreno Cárdenas and Albuja 2014; Zeballos et al. 2018). However, the presence of $C$. equatoris and $C$. niausa is expected in Colombia, because of the vegetation similarities and the lack of geographic or other ecological barriers between the Andean part of southwestern Colombia and northern Ecuador (Ramírez-Chaves and Noguera-Urbano 2011; Noguera-Urbano et al. 2019).

Cryptotis niausa is currently known from nine localities in the Ecuadorian provinces of Carchi, Napo, and Pichincha, ranging in elevational from 2,865 to 3,910 m a.s.1. (Moreno Cárdenas and Albuja 2014; Zeballos et al. 2018), with an estimated Extent of Occurrence (EOO) of $5,036 \mathrm{~km}^{2}$ (Roach and Naylor 2020). It is among the largest Cryptotis (head and body length: 74-89 mm; condylo-basal length: $21.8-23.7 \mathrm{~mm}$ ), and it can be differentiated by its size, cranial and dental characters, and genetic data (Moreno Cárdenas and Albuja 2014; Zeballos et al. 2018). The species is currently listed as Data Deficient by the International Union for Conservation of Nature because of the lack of information on population or threats (Roach and Naylor 2020). To contribute to the knowledge of this little-known species, we present the first record of C. niausa from the Andes of southwestern Colombia based on morphological and genetic data.

\section{Methods}

The first confirmed record of Cryptotis niausa from Colombia is based on a single specimen found dead in the Department of Nariño, southwestern Colombia in March 2020. The specimen was preserved in ethanol $(70 \%)$ with the skull removed and cleaned. The specimen is deposited at the Museo de Historia Natural de la Universidad de Caldas (MHN-UCa) in Manizales, Caldas, Colombia. To identify the specimen, we followed the taxonomic keys and descriptions suggested by Woodman and Péfaur (2008), Moreno Cárdenas and Albuja (2014), and Zeballos et al. (2018). We also took the following external and cranial measurements to the nearest 0.01 $\mathrm{mm}$ using digital calipers (Table 1), including head and body length (HB), tail length (TL) hind foot length (HF), and 20 craniodental measurements including: condylobasal length $(\mathrm{CBL})$, cranial breadth $(\mathrm{CB})$, breadth of zygomatic plate (ZP), interorbital breadth (IO), breadth across first unicuspids (U1B), breadth across third unicuspids (U3B), breadth across second molars (M2B), palatal length (PL), length of upper toothrow (TR), length of unicuspid toothrow (UTR), length of molariform toothrow (MTR), posterior width of M1 across hypocone and metastyle (WM1), length of mandible (ML), maxillary row length (MRL), height of coronoid process (HCP), height of coronoid valley (HCV), height of articular condyle (HAC), distance from the articular condyle to the posterior edge of third lower molar (AC3), length of first lower molar (Lm1), and length of lower molar row (TRD). We also took body mass (W) in grams. In addition, we performed DNA extraction from liver tissue preserved in $70 \%$ ethanol (stored at room temperature) using Wizard $\AA$ Genomic DNA Purification kit (Promega Corporation) following the protocol proposed by the manufacturer. We amplified the sequence by Polymerase Chain Reaction (PCR), using mitochondrial marker cytochrome $b$ (cyt $\mathrm{b} ; \approx 1140 \mathrm{pb}$ ) gene. Primers used in DNA amplification are LGL 765 5'-GAAAAACCAYCGTTGTWATTCAACT-3' (Bickham et al. 1995) and LGL 766 5'-GTTTAATTAGAATYTYAGCTTTGGG-3' (Bickham et al. 2004). The products were visualized by electrophoresis in $1 \%$ agarose gels with a molecular weight marker $(1 \mathrm{~Kb})$ and $5 \times$ running buffer. To ensure the quality of the DNA fragments obtained, we quantified them by fluorometry on a Quantus Fluorometer ${ }^{\mathrm{TM}}$ (Promega $\left.{ }^{\circledR}\right)$, and sent to Macrogen Inc. (South Korea) for DNA purification and sequencing. The sequence obtained was edited in the Geneious Prime v. 2019.2.3 program. To verify the correct identity of the sequence, it was searched by Blast against the public databases, and we downloaded sequences of closely related taxa available in GenBank and reported by Zeballos et al. (2018). We used 112 sequences of cytochrome $b$ gene in total using Blarina brevicauda (Say, 1823), Blarinella quadraticauda (Milne-Edwards, 1872), and Episoriculus leucops (Horsfield, 1855) as outgroups (Supplemental data). The sequences were aligned using Clustal W (Thompson et al. 1997), included in the program MEGA X (Kumar et al. 2018); furthermore, we selected the best substitution model for the gene. We selected the Akaike Information Criterion (AIC) values for the maximum likelihood analysis, with PhyML 3.0 online execution (Guindon et al. 2010). The poisson tree processes (PTP) model identifies putative species boundaries on a given phylogenetic input tree (Zhan et al. 2013). The input tree was obtained by an updated version of the original maximum likelihood PTP (maximum likelihood PTP search result is part of the bPTP results), which adds Bayesian support (BS) values to species delimited on the input tree and displayed in FigTree v. 1.3.1 (Rambaut and Drummond 2010). A higher BS value (close to 1) on a species level node indicates that all descendants from this node are more likely to belong to a single species. Genetic distances were estimated with the Kimura 2 parameters evolution model (K2P; Kimura 1980) with the software MEGA.

We compiled all available localities in the literature (Table 2) to update the distribution (Moreno Cárdenas and Albuja 2014; Zeballos et al. 2018). We estimated the species EOO using the minimum convex polygon in GeoCAT (Bachman et al. 2011). Finally, we calculated the distribution area and list of the terrestrial biomes and ecoregions that $C$. niausa inhabits (Olson et al. 2001). 

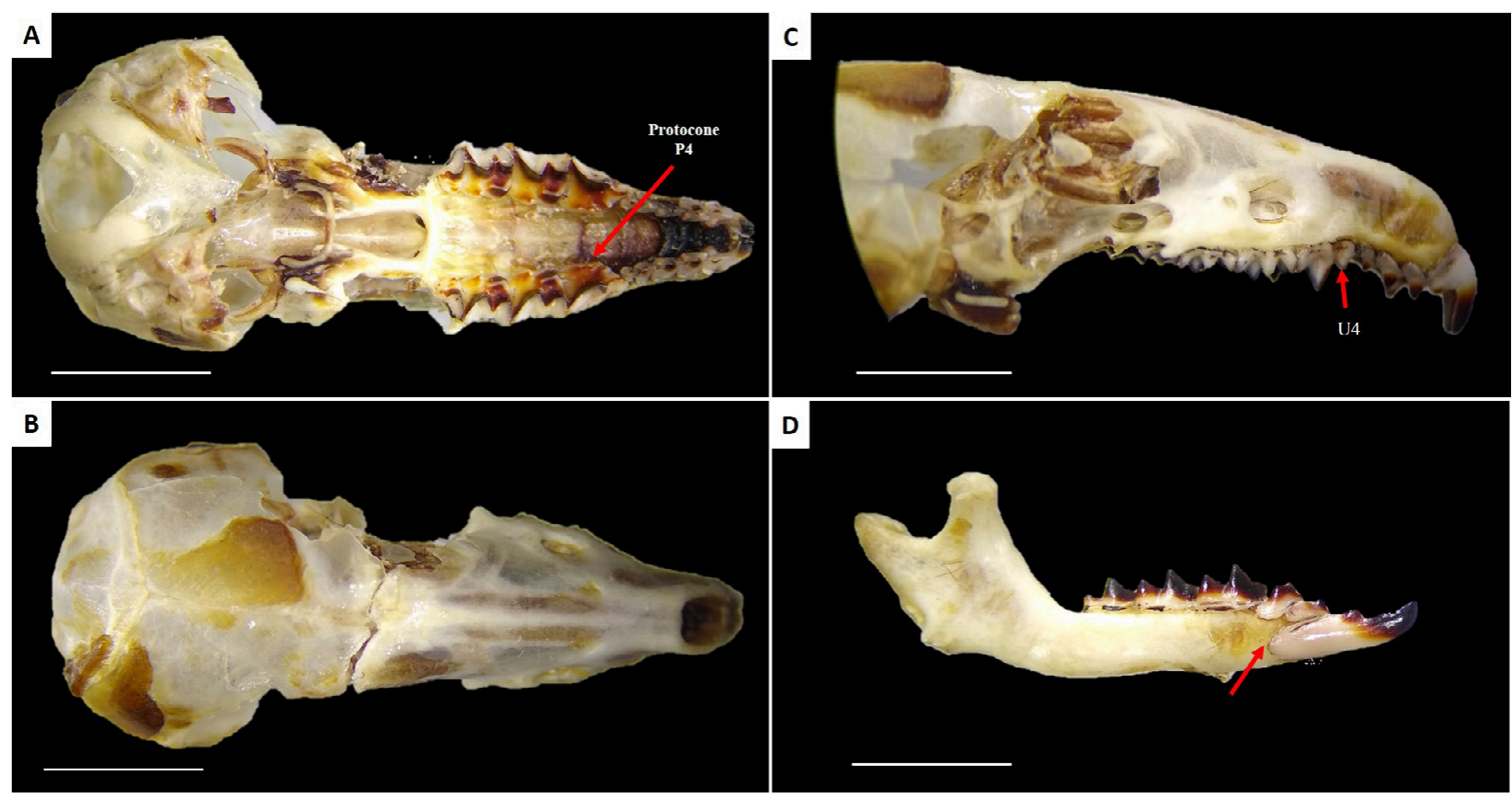

Figure 1. Skull of Cryptotis niausa (MHN-UCa-M 3298) from the Departamento de Nariño, Colombia. A. Ventral view. B. Dorsal view. C. Lateral view. D. Details of the mandible. Note the posterior edge of the lower incisor that does not exceed p4 (arrow in D) which has been suggested as a diagnostic character of C. niausa. Scale bars: $10 \mathrm{~mm}$.

\section{Results}

\section{Cryptotis niausa Moreno Cárdenas \& Albuja, 2014}

New record. COLOMBIA - Departamento de Nariño - Municipality of Guachucal, Los Capotes, "Resguardo" Muellamues”, Laguna La Bolsa; 00 $57^{\prime} 39^{\prime \prime} \mathrm{N}, 077^{\circ} 48^{\prime}$ 54"W; 3,437 m elev.; 13.III.2020; Daniela Velásquez G. leg.; found dead on a hiking trail near to La Bolsa Lake; GenBank accession code: MW584267; 1 \%, fluid preserved (alcohol 70\%), with skull removed (Fig. 1), MHN-UCa-M 3298.

Identification. MHN-UCa-M 3298 presents a general greyish coat color, which is almost uniform dorsally and ventrally. The coat is approximately $90 \%$ light neutral gray, and the tips are generally olive brown. The belly coat is almost entirely dark neutral gray, and the apical portion has a clay color, accentuating a yellowish-brown color throat and chest. A combination of additional external traits that match those of $C$. niausa include the large body (HB: between 74 and $89 \mathrm{~mm}$; Table 1). The tail is short, with $42 \%$ in size relation of the HB length, generally dark gray, covered with barely visible scales with short whitish-gray hairs. Cranially, the specimen MHN-UCa-M 3298 presents the posterior border of the palatine well separated from the posterior cingulate of the upper third molars and slightly arched (Fig. 1A). The face is moderately long $(\mathrm{PL} / \mathrm{CBL}=44 \%)$ and narrow $(\mathrm{M} 2 \mathrm{~B} / \mathrm{CBL}=27.4 \%)$, with a narrow nasal opening and a narrow interorbital region (Fig. 1B). The zygomatic plate is narrow relative to the CBL. The unicuspid row is short and narrow; U4 is small, generally less than or equal to half the area occupied by $\mathrm{U} 3$, but visible laterally on the skull. U3 is aligned with the other unicuspids, preventing contact between $\mathrm{U} 3$ and $\mathrm{P} 4$, and the protocone of $\mathrm{P} 4$ is slightly extended lingually (Fig. 1C). The mandible is long $(\mathrm{ML}=7.3 \mathrm{~mm})$, with short coronoid process $(\mathrm{HCP} /$ $\mathrm{ML}=63 \%)$ and oriented towards the labial side of the jaw. The articular condyle is high ( $\mathrm{HCA} / \mathrm{LM}=60.3 \%$ ); the lower incisors measure an average of $4.4 \mathrm{~mm}$ and their posterior borders do not reach the level of the posterior border of the $\mathrm{p} 4$ (Fig. 1D). The 1,044 bp cytochrome $b$ sequence [MW584267] showed a 99.0-99.6\% identity and genetic distance of $0.4 \%$ with $C$. niausa sequences from Ecuador [MH352624, MH352625, MH352629].

The best evolutionary model was GTR $+\mathrm{G}+\mathrm{I}$ for cytochrome $b$. The gene tree constructed using maximum likelihood PTP and species nodes were well supported (Fig. 2 and Supplemental data). Cytochrome $b$ sequences of $C$. niausa from Ecuador and Colombia were grouped in a clade with $100 \%$ bootstrap support. Cytochrome $b$ distances at the intraspecific level ranged between 0.0 and $2.0 \%$ in all species of genus Cryptotis, included $C$. niausa with an intraspecific distance between 0.0 and $0.4 \%$ (Maximum likelihood partition support $=0.866$ ). Interspecific divergence of the 26 species of Cryptotis included in this study ranged between $1.6 \%$ and $18.8 \%$ (Table 3).

Distribution update. The new record from Colombia was found in a locality dominated by high Andean forests and grasslands close to páramo (Espeletia pycnophylla Cuatrec.) vegetation that are part of the Northwest Andean Montane Forests ecoregion. The locality records of C. niausa in Ecuador (nine localities) are part of two ecoregions, the Northwest Andean Montane Forests and the Northern Andean Paramo (Fig. 3). Three localities of the Northern Andean Paramo are close to the limits of 
Table 1. Cranial and external measurements of Cryptotis niausa from Colombia (MHN-UCa-M 3298), and C. niausa, C. equatoris, and C. osgoodi from Ecuador. Mean and standard deviation (range). Measurements from Ecuador were taken from Moreno Cárdenas and Albuja (2014; column A), and Zeballos et al. (2018; column B). Abbreviations are explained in the text.

\begin{tabular}{|c|c|c|c|c|c|c|c|}
\hline \multirow{2}{*}{$\begin{array}{l}\text { Taxon } \\
\text { Measurement }\end{array}$} & \multicolumn{3}{|c|}{ Cryptotisniausa } & \multicolumn{2}{|c|}{ C.osgoodi } & \multicolumn{2}{|c|}{ C. equatoris } \\
\hline & Colombia & A & B & A & B & A & B \\
\hline$H B$ & 79 & $\begin{array}{l}81.0 \pm 4.3 \\
(74-89) 15\end{array}$ & $\begin{array}{l}77.7 \pm 10.52 \\
(54.5-93) 15\end{array}$ & $\begin{array}{c}76.7 \pm 5 \\
(70-83) 7\end{array}$ & $\begin{array}{c}68.7 \pm 9.55 \\
(54-76) 7\end{array}$ & $\begin{array}{l}74.5 \pm 6.2 \\
(63.8-86) 8\end{array}$ & $\begin{array}{c}65.73 \pm 9.20(56.2- \\
76) 3\end{array}$ \\
\hline HF & 15.7 & $\begin{array}{l}13.3 \pm 0.8 \\
(12-15) 9\end{array}$ & $\begin{array}{c}14.7 \pm 1.02 \\
(13.4-17.4) 15\end{array}$ & $\begin{array}{l}13.1 \pm 0.7 \\
(12-14) 7\end{array}$ & $\begin{array}{c}13.67 \pm 1.15(12.0- \\
15.0) 7\end{array}$ & $\begin{array}{c}13.6 \pm 1.1 \\
(12.7-16) 8\end{array}$ & $\begin{array}{c}13.47 \pm 1.36(12.4- \\
15.0) 3\end{array}$ \\
\hline $\mathrm{TL}$ & 35 & $\begin{array}{c}34.0 \pm 2.4 \\
(29.8-37) 9\end{array}$ & $\begin{array}{c}35.5 \pm 3.06 \\
(30-40.8) 14\end{array}$ & $\begin{array}{r}30.3 \pm 2.8 \\
(26-33) 7\end{array}$ & $\begin{array}{c}29.9 \pm 3.58 \\
(24-35) 7\end{array}$ & $\begin{array}{c}36.2 \pm 2.0 \\
(33.7-40) 8\end{array}$ & $\begin{array}{c}31.87 \pm 1.85(30- \\
33.7) 3\end{array}$ \\
\hline W & 15 & - & $\begin{array}{l}14.4 \pm 1.79 \\
(12-17) 15\end{array}$ & - & $8.64 \pm 2.88(6-13) 7$ & - & $9.53 \pm 0.72(8.7-10) 3$ \\
\hline CBL & 22.6 & $\begin{array}{c}22.6 \pm 0.7 \\
(21.8-23.7) 15\end{array}$ & $\begin{array}{c}21.21 \pm 0.45 \\
(20.77-21.85) 5\end{array}$ & - & $\begin{array}{c}19.67 \pm 0.75(18.23- \\
20.65) 7\end{array}$ & $\begin{array}{c}21.3 \pm 0.3 \\
(21-21.95) 8\end{array}$ & $\begin{array}{c}20.32 \pm 0.28(20.10- \\
20.63) 3\end{array}$ \\
\hline CB & 9.7 & $\begin{array}{c}10.7 \pm 0.3(10.35- \\
11.35) 15\end{array}$ & $\begin{array}{c}10.38 \pm 0.34 \\
(9.96-10.91) 5\end{array}$ & $\begin{array}{c}9.8 \pm 0.4 \\
(9.15-10.25) 9\end{array}$ & $\begin{array}{l}9.54 \pm 0.46 \\
(8.74-10.14) 7\end{array}$ & $\begin{array}{c}10.3 \pm 0.4 \\
(9.75-10.85) 8\end{array}$ & $\begin{array}{c}9.86 \pm 0.46(9.38- \\
10.29) 3\end{array}$ \\
\hline ZP & 2.5 & $\begin{array}{c}1.9 \pm 0.3 \\
(1.3-2.2) 15\end{array}$ & $\begin{array}{c}2.00 \pm 0.17 \\
(1.75-2.13) 5\end{array}$ & $\begin{array}{c}1.9 \pm 0.1 \\
(1.74-2.1) 12\end{array}$ & $\begin{array}{c}2.26 \pm 0.15 \\
(2.03-2.48) 7\end{array}$ & $\begin{array}{c}2.2 \pm 0.1 \\
(2.16-2.35) 9\end{array}$ & $\begin{array}{c}3(2.19-2.38) 3 \\
2.3 \pm 0.1\end{array}$ \\
\hline 10 & 5.01 & $\begin{array}{c}5.5 \pm 0.2 \\
(5.2-5.85) 15\end{array}$ & $\begin{array}{c}4.86 \pm 0.15 \\
(4.63-5.02) 5\end{array}$ & $\begin{array}{c}5.4 \pm 0.2 \\
(4.9-5.6) 12\end{array}$ & $\begin{array}{c}4.67 \pm 0.26 \\
(4.27-4.99) 7\end{array}$ & $\begin{array}{c}5.6 \pm 0.2 \\
(5.33-5.94) 9\end{array}$ & $\begin{array}{c}3(4.70-4.94) 3 \\
4.86 \pm 0.14\end{array}$ \\
\hline U1B & 2.65 & $\begin{array}{c}2.5 \pm 0.3 \\
(1.8-2.8) 15\end{array}$ & $\begin{array}{l}2.55 \pm 0.16 \\
(2.3-2.74) 5\end{array}$ & $\begin{array}{c}2.5 \pm 0.1 \\
(2.3-2.6) 12\end{array}$ & $\begin{array}{c}2.46 \pm 0.13 \\
(2.33-2.60) 7\end{array}$ & $\begin{array}{c}2.6 \pm 0.1 \\
(2.5-2.7) 9\end{array}$ & $\begin{array}{c}2.44 \pm 0.20(2.21- \\
2.59) 3\end{array}$ \\
\hline U3B & 2.98 & $\begin{array}{c}3.0 \pm 0.2 \\
(2.5-3.23) 15\end{array}$ & $\begin{array}{c}3.35 \pm 0.32 \\
(3.13-3.68) 5\end{array}$ & $\begin{array}{c}2.9 \pm 0.2 \\
(2.7-3.15) 12\end{array}$ & $\begin{array}{c}2.93 \pm 0.31 \\
(2.60-3.38) 7\end{array}$ & $\begin{array}{c}3.0 \pm 0.2 \\
(2.8-3.35) 9\end{array}$ & $\begin{array}{c}2.91 \pm 0.17(2.81- \\
3.11) 3\end{array}$ \\
\hline$M 2 B$ & 5.78 & $\begin{array}{c}6.2 \pm 0.2 \\
(5.86-6.46) 15\end{array}$ & $\begin{array}{c}5.79 \pm 0.7 \\
(5.43-6.13) 5\end{array}$ & $\begin{array}{c}5.8 \pm 0.1 \\
(5.5-5.97) 12\end{array}$ & $\begin{array}{c}5.65 \pm 0.12 \\
(5.49-5.85) 7\end{array}$ & $\begin{array}{c}6.1 \pm 0.3 \\
(5.7-6.5) 9\end{array}$ & $\begin{array}{c}5.95 \pm 0.24(5.79- \\
6.22) 3\end{array}$ \\
\hline PL & 8.82 & $\begin{array}{c}9.8 \pm 0.3 \\
(9.22-10.29) 15\end{array}$ & $\begin{array}{c}9.56 \pm 0.17 \\
(9.37-9.79) 5\end{array}$ & $\begin{array}{c}8.9 \pm 0.4 \\
(8.0-9.5) 12\end{array}$ & $\begin{array}{l}8.74 \pm 0.46 \\
(7.91-9.32) 7\end{array}$ & $\begin{array}{l}9.3 \pm 0.2 \\
(9-9.65) 9\end{array}$ & $\begin{array}{c}8.98 \pm 0.21(8.80- \\
9.21) 3\end{array}$ \\
\hline TR & 8.60 & & $\begin{array}{c}7.98 \pm 0.40 \\
(7.49-8.55) 5\end{array}$ & - & $\begin{array}{c}7.72 \pm 0.22 \\
(7.32-7.98) 7\end{array}$ & - & $\begin{array}{c}8.08 \pm 0.25(7.79- \\
8.25) 3\end{array}$ \\
\hline UTR & 2.43 & $\begin{array}{c}2.76 \pm 0.3 \\
(2.0-3.07) 15\end{array}$ & $\begin{array}{c}2.66 \pm 0.08 \\
(2.57-2.78) 5\end{array}$ & $\begin{array}{c}2.6 \pm 0.2 \\
(2.2-2.9) 12\end{array}$ & $\begin{array}{l}2.69 \pm 0.35 \\
(2.34-3.18) 7\end{array}$ & $\begin{array}{c}2.6 \pm 0.1 \\
(2.5-2.75) 9\end{array}$ & $\begin{array}{c}2.55 \pm 0.22(2.30- \\
2.68) 3\end{array}$ \\
\hline MTR & 6.29 & & $\begin{array}{c}5.65 \pm 0.37 \\
(5.11-5.99) 15\end{array}$ & & $\begin{array}{c}5.41 \pm 0.15 \\
(5.14-5.61) 7\end{array}$ & & $\begin{array}{c}5.79 \pm 0.26(5.49- \\
5.97) 3\end{array}$ \\
\hline MRL & 9.25 & $\begin{array}{c}8.5 \pm 0.3 \\
(8.08-9.0) 15\end{array}$ & & $\begin{array}{c}7.7 \pm 0.3 \\
(7.15-8) 12\end{array}$ & & $\begin{array}{c}8.1 \pm 0.2 \\
(7.86-8.35) 9\end{array}$ & \\
\hline WM1 & 1.83 & - & $\begin{array}{c}1.30 \pm 0.14 \\
(1.19-1.54) 15\end{array}$ & - & $\begin{array}{c}1.60 \pm 0.14 \\
(1.42-1.80) 7\end{array}$ & - & $\begin{array}{c}1.76 \pm 0.15 \\
(1.59-1.87) 3\end{array}$ \\
\hline$M L$ & 7.95 & $\begin{array}{c}7.4 \pm 0.3 \\
(6.73-8) 15\end{array}$ & $\begin{array}{c}7.32 \pm 0.57 \\
(6.84-8.28) 5\end{array}$ & $\begin{array}{c}6.7 \pm 0.1 \\
(6.6-7.0) 12\end{array}$ & $\begin{array}{c}6.62 \pm 0.48 \\
(5.95-7.35) 7\end{array}$ & $\begin{array}{c}7.1 \pm 0.2 \\
(6.98-7.58) 9\end{array}$ & $\begin{array}{c}6.84 \pm 0.21 \\
(6.65-7.06) 3\end{array}$ \\
\hline HCP & 4.73 & & $\begin{array}{c}4.50 \pm 0.16 \\
(4.22-4.61) 5\end{array}$ & $\begin{array}{c}4.3 \pm 0.1 \\
(4.1-4.6) 12\end{array}$ & $\begin{array}{c}4.09 \pm 0.15 \\
(3.89-4.30) 7\end{array}$ & $\begin{array}{c}4.5 \pm 0.2 \\
(4.21-4.67) 9\end{array}$ & $\begin{array}{c}4.48 \pm 0.16 \\
(4.33-4.65) 3\end{array}$ \\
\hline $\mathrm{HCV}$ & 3.18 & $\begin{array}{c}3.1 \pm 0.3 \\
(2.75-3.8) 15\end{array}$ & $\begin{array}{c}3.21 \pm 0.38 \\
(2.88-3.86) 5\end{array}$ & $\begin{array}{c}2.7 \pm 0.1 \\
(2.52-2.92) 12\end{array}$ & $\begin{array}{c}2.76 \pm 0.12 \\
(2.50-2.87) 7\end{array}$ & $\begin{array}{c}3.0 \pm 0.1 \\
(2.87-3.1) 9\end{array}$ & $\begin{array}{c}2.84 \pm 0.13 \\
(2.71-2.79) 3\end{array}$ \\
\hline HAC & 4.51 & $\begin{array}{c}4.4 \pm 0.2 \\
(4-4.7) 15\end{array}$ & $\begin{array}{c}4.00 \pm 0.09 \\
(3.89-4.09) 5\end{array}$ & $\begin{array}{c}3.8 \pm 0.2 \\
(3.5-4) 12\end{array}$ & $\begin{array}{c}3.59 \pm 0.26 \\
(3.24-4.10) 7\end{array}$ & $\begin{array}{c}4.0 \pm 0.1 \\
(3.8-4.24) 9\end{array}$ & $\begin{array}{c}3.93 \pm 0.94 \\
(3.66-4.13) 3\end{array}$ \\
\hline $\mathrm{AC} 3$ & 5.93 & - & $\begin{array}{l}5.46 \pm 0.34 \\
(5.13-6.0) 5\end{array}$ & - & $\begin{array}{c}4.82 \pm 0.40 \\
(4.41-5.39) 7\end{array}$ & - & $\begin{array}{c}5.61 \pm 0.19 \\
(5.44-5.82) 3\end{array}$ \\
\hline TRD & 6.77 & & $\begin{array}{c}6.37 \pm 0.21 \\
(6.11-6.67) 5\end{array}$ & & $\begin{array}{c}5.89 \pm 0.21 \\
(5.56-6.16) 7\end{array}$ & & $\begin{array}{c}5.90 \pm 0.32 \\
(5.59-6.23) 3\end{array}$ \\
\hline Lm1 & 1.76 & $\begin{array}{c}2.0 \pm 0.1 \\
(1.72-2.15) 15\end{array}$ & $\begin{array}{r}1.90 \pm 0.10 \\
(1.74-2.0) 5\end{array}$ & $\begin{array}{c}1.9 \pm 0.1 \\
(1.87-2.05) 12\end{array}$ & $\begin{array}{l}1.86 \pm 0.09 \\
(1.74-2.0) 7\end{array}$ & $\begin{array}{c}2.0 \pm 0.1 \\
(1.9-2.1) 9\end{array}$ & $\begin{array}{c}1.90 \pm 0.04 \\
(1.86-1.93) 3\end{array}$ \\
\hline
\end{tabular}

the Eastern Cordillera Real Montane Forests (Fig. 3). The estimated EOO for both countries is $3,850 \mathrm{~km}^{2}$.

\section{Discussion}

We confirmed the presence of Cryptotis niausa in Colombia, extending the known distribution of this species $28.3 \mathrm{~km}$ north from the closest record in Ecuador (Moreno Cárdenas and Albuja 2014; Zeballos et al. 2018). This finding also confirms previous statements that the diversity of shrews in Colombia is underestimated
(Noguera-Urbano et al. 2019). With our record, $C$. niausa is currently known from 10 localities (Table 2) and two ecoregions (Fig. 3), the Northwest Andean Montane Forests (Colombia and Ecuador) and the Northern Andean Paramo (Ecuador). Both ecoregions are shared by Colombia and Ecuador (Olson et al. 2001); therefore, the northern and southern distributional limits are almost certainly within these two countries. The northern limits of the distribution of C. niausa in Colombia are unclear but might be limited to the Macizo Colombiano (Colombian Massif). The Macizo Colombiano is an orographic complex region of the Andes of southwestern Colombia 


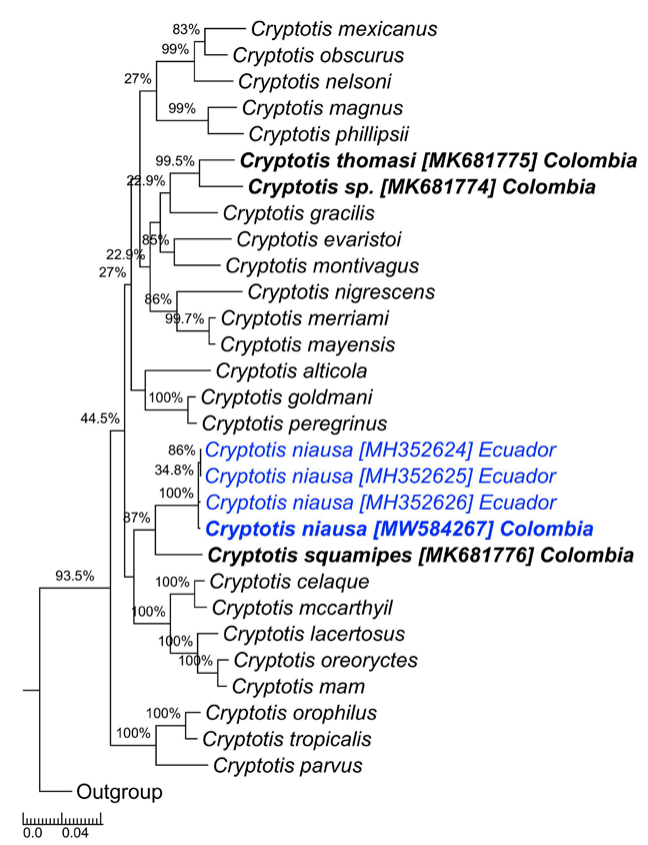

Figure 2. A summary of the maximum likelihood phylogram based on the DNA sequence data set of 26 Cryptotis species using 1,440 positions for the cytochrome $b$ gene. Scores are bootstrap support values from the maximum likelihood analysis. New sequence of $C$. niausa reported in this study and all sequences of Cryptotis species reported for Colombia are shown in bold. A detailed tree including additional individuals of each species and other external groups is shown in Supplemental Fig. S1. where the two cordilleras in Ecuador constitute a single mountainous massif (Noguera-Urbano 2016). At the northern end of the Macizo Colombiano, the climate is dry (upper tropical to subtropical), acting as a barrier to temperate-zone mammals (Hershkovitz 1982). This area has been suggested as the boreal limit of the distribution of other mammals such as Culpeo, Lycalopex culpaeus (Molina, 1782), and Hog-nosed Skunk, Conepatus semistriatus quitensis (Humboldt, 1812) (Hershkovitz 1982; Voss 2003; Ramírez-Chaves and Noguera-Urbano 2011; Noguera-Urbano et al. 2016). The southern distributional limits might reach the southern border of the Northwest Andean Montane Forests in the Andean part of the Province Zamora Chinchipe in Ecuador. Fieldwork should be done to explore both northern and southern limits of the distribution of $C$. niausa. On the other hand, the estimated EEO including the new record from Colombia is also lower $\left(3,850 \mathrm{~km}^{2}\right)$ than previous values estimated only for Ecuador $\left(5,036 \mathrm{~km}^{2}\right)$ (Roach and Naylor 2020). Based only on EOO, this species might be Endangered; however, severe fragmentation or continuing declines and extreme fluctuations are unknown.

Our molecular phylogenetic results and the genetic distances also corroborates the presence of C. niausa in Colombia (Fig. 2). Molecular information of shrews from Colombia is limited, with only four of the eight Cryptotis

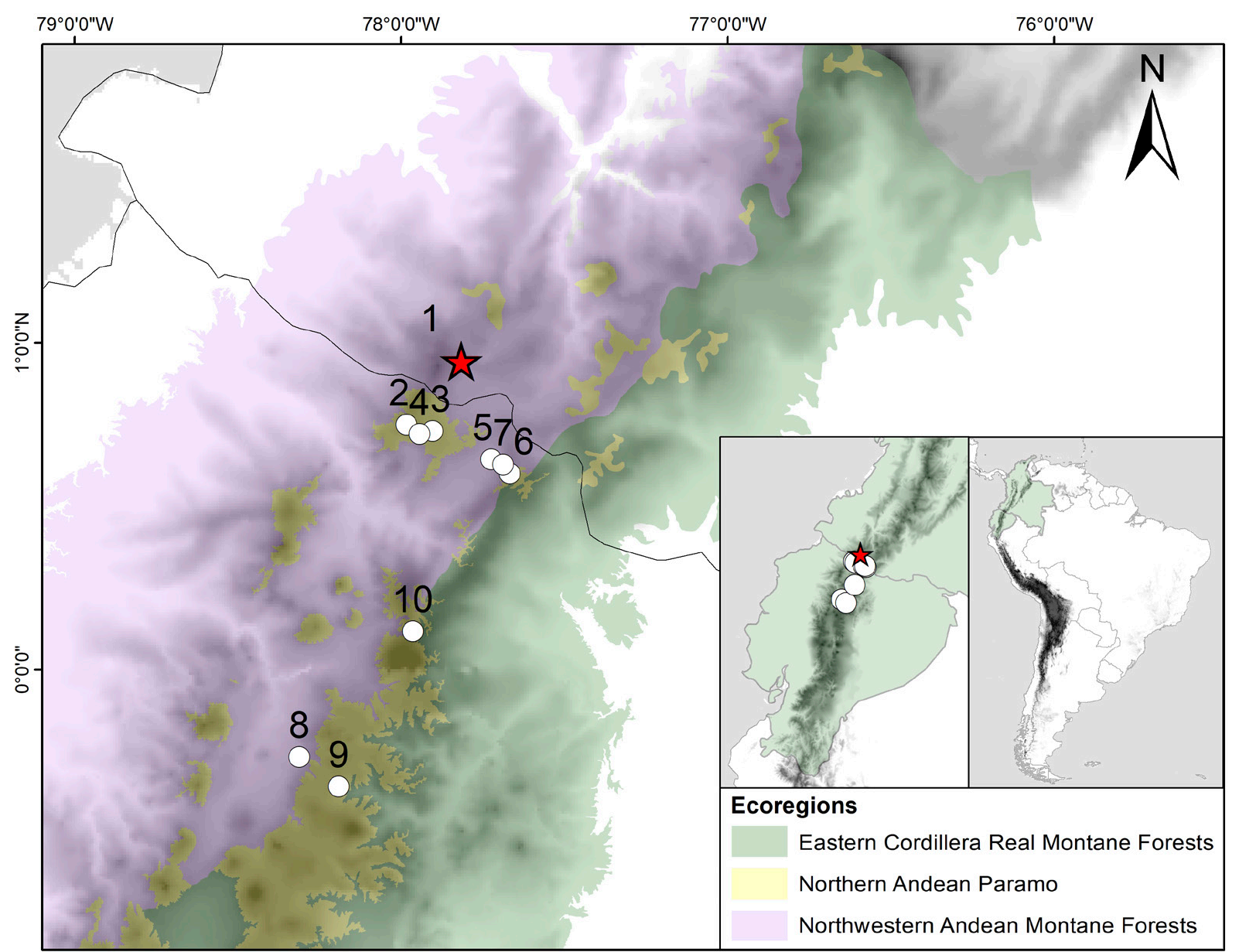

Figure 3. Updated distribution of Cryptotis niausa in Colombia and Ecuador. New records (red star) based on the specimen MHN-UCa-M 3298. Localities from Ecuador in the literature (black dots). The number of each locality is shown in Table 1. 
Table 2. Locality records of Cryptotis niausa in Colombia and Ecuador. Abbreviations are: MEPN: Museo Escuela Politécnica Nacional (Ecuador), MECN: Museo Ecuatoriano de Ciencias Naturales (Ecuador), MHN-UCa: Museo de Historia Natural, Universidad de Caldas (Colombia), QCAZ: Museo de la Pontificia Universidad Católica del Ecuador (Ecuador). Localities from Ecuador were obtained from Moreno Cárdenas and Albuja (2014). The ecoregions followed Olson et al. (2001) and are: NAMF: Northwest Andean Montane Forests, NAP: Northern Andean Paramo.

\begin{tabular}{lllclll}
\hline Country & Locality & Ecoregion & $\begin{array}{c}\text { Eleva- } \\
\text { tion }(\mathbf{m})\end{array}$ & Latitude & Longitude & Reference \\
\hline Colombia & Nariño: Guachucal, Laguna La Bolsa, Los Capotes & NAMF & 3437 & 00.9441 & -077.8150 & MHN-UCa-M 3298; this study \\
Ecuador & Carchi: Páramos del Azuay & NAP & 3910 & 00.7500 & -077.9833 & MEPN 280 \\
Ecuador & Carchi: Lagunas de "El Voladero" & NAP & 3700 & 00.7300 & -077.9030 & MEPN 9791, QCAZ2309 \\
Ecuador & Carchi: Páramos del Ángel & NAP & 3600 & 00.7207 & -077.9429 & MEPN 9790 \\
Ecuador & Carchi: Quebrada Tunguetan & NAMF & 2865 & 00.6438 & -077.7238 & QCAZ3520 \\
Ecuador & Carchi: Páramos de la Reserva Ecológica Guanderas & NAP & 3500 & 00.6000 & -077.6666 & MEPN \\
Ecuador & Carchi: Huaca, Estación Biológica Guandera & NAMF & 3400 & 00.6280 & -077.6871 & MEPN 10617 \\
Ecuador & Pichincha: Río Palobillo, Itulcachi & NAMF & 3800 & -00.2677 & -078.3122 & MEPN 283 \\
Ecuador & Napo: Papallacta, "La Virgen" & NAP & 3700 & -00.3580 & -078.1914 & MEPN 9627 [holotype], MEPN 9628, 9832,9833, 10613, 10615 \\
Ecuador & Pichincha: Parque Nacional Cayambe-Coca, Sector de San Marcos & NAP & 3560 & 00.1171 & -077.9635 & MEPN 12569 \\
\hline
\end{tabular}

species found in Colombia having genetic information (Noguera-Urbano et al. 2019). The cytochrome $b$ sequence obtained here is the fifth known for the species (Zeballos et al. 2018). The cytochrome $b$ distances observed between the record from Colombia and from additional localities in Ecuador are within the intraspecific values observed in mammals (Bradley and Baker 2001; Baker and Bradley 2006), including South American shrews of genus Cryptotis ( $2.5 \%$; Zeballos et al. 2018).

Finally, the topology found in our phylogenetic analyses (Fig. 2) is similar to the previous work that includes sequences from Colombia (Noguera-Urbano et al. 2019), with $C$. niausa showing no clear association to any of the two species groups with presence in Colombia (thomasi and nigrescens groups) defined based on morphological characters (Woodman and Péfaur 2008). Despite the small sample size, the genetic information available allowed us to understand the diversity of shrews of genus Cryptotis in Colombia. Nonetheless, integration of the other species is necessary for future research that will help to clarify the taxonomy and distribution of the genus Cryptotis in South America.

\section{Acknowledgements}

We thank the Vicerrectoría de Postgrados e investigaciones of the Universidad de Caldas, Manizales for support to the grupo de Investigación en Genética, Biodiversidad y Manejo de Ecosistemas during 2020. We also thank Darwin Morales Martínez for helping with the distribution map and Robert Timm, William Tavares, and two anonymous reviewers for useful comments to early versions of this manuscript. IYMF thanks the "Programa Jóvenes Investigadores" call No. 891 of 2020 "Fortalecimiento de vocaciones y formación en CTeI para la reactivación económica en el marco de la postpandemia 2020", for support. HER-C thanks Vicerrectoría de Investigaciones, Universidad de Caldas (project 0743919), and The Rufford Foundation (grants 23710-1 and 29491-2).

\section{References}

Bachman S, Moat J, Hill AW, De la Torre J, Scott B (2011) Supporting Red List threat assessments with Geo CAT: geospatial conservation assessment tool. ZooKeys 150: 117-126. https://doi. org/10.3897/zookeys.150.2109

Baird AB, Mccarthy TJ, Trujillo RG, Kang YY, Esmaeiliyan M, Valdez J, Woodman N, Bickham JW (2018) Molecular systematics and biodiversity of the Cryptotis mexicanus group (Eulipotyphla: Soricidae): two new species from Honduras supported. Systematics and Biodiversity 16: 108-117. https://doi.org/10.1080/1477200 0.2017 .1333539

Baker RJ, Bradley RD (2006) Speciation in mammals and the genetic species concept. Journal of Mammalogy 87: 643-662. https://doi. org/10.1644/06-mamm-f-038r2.1

Bickham JW, Wood CC, Patton JC (1995) Biogeographic implications of cytochrome $b$ sequences and allozymes in sockeye $(\mathrm{On}$ corhynchus nerka). Journal of Heredity 86: 140-144. https://doi. org/10.1093/oxfordjournals.jhered.a111544

Bickham JW, Patton JC, Schlitter DA, Rautenbach IL, Honeycutt RL (2004) Molecular phylogenetics, karyotypic diversity, and partition of the genus Myotis (Chiroptera: Vespertilionidae). Molecular Phylogenetics and Evolution 33: 333-338. https://doi.org/10.1016/j. ympev.2004.06.012

Bradley RD, Baker RJ (2001) A test of the genetic species concept: cytochrome- $b$ sequences and mammals. Journal of Mammalogy 82 : 960-973. https://doi.org/10.1644/1545-1542(2001)082<0960:atotg $\mathrm{s}>2.0 . \mathrm{co} ; 2$

Brant SV, Orti G (2002) Molecular phylogeny of short-tailed shrews, Blarina (Insectivora: Soricidae). Molecular Phylogenetics and Evolution 22: 163-173. https://doi.org/10.1006/mpev.2001.1057

Guevara L, Cervantes FA (2014) Molecular systematics of small-eared shrews (Soricomorpha, Mammalia) within Cryptotis mexicanus species group from Mesoamérica. Acta Theriologica 59: 233-242. https://oi.org/10.1007/s13364-013-0165-6

Guindon S, Dufayard JF, Lefort V, Anisimova M, Hordijk W, Gascuel O (2010) New algorithms and methods to estimate maximumlikelihood phylogenies: assessing the performance of PhyML 3.0. Systematic Biology 59: 307-321. https:/doi.org/10.1093/sysbio/ syq010

Hershkovitz P (1982) Neotropical deer (Cervidae) Part 1. Pudus genus Pudu Gray. Fieldiana: Zoology New Series 11: 1-86. https://doi. org/10.5962/bhl.title. 5080

Kumar S, Stecher G, Li M, Knyaz C, Tamura K (2018) MEGA X: Molecular Evolutionary Genetics Analysis across computing platforms. Molecular Biology and Evolution 35: 1547-1549. https:// doi.org/10.1093/molbev/msy096

Moreno Cárdenas PA, Albuja V L (2014) Una nueva especie de mu- 


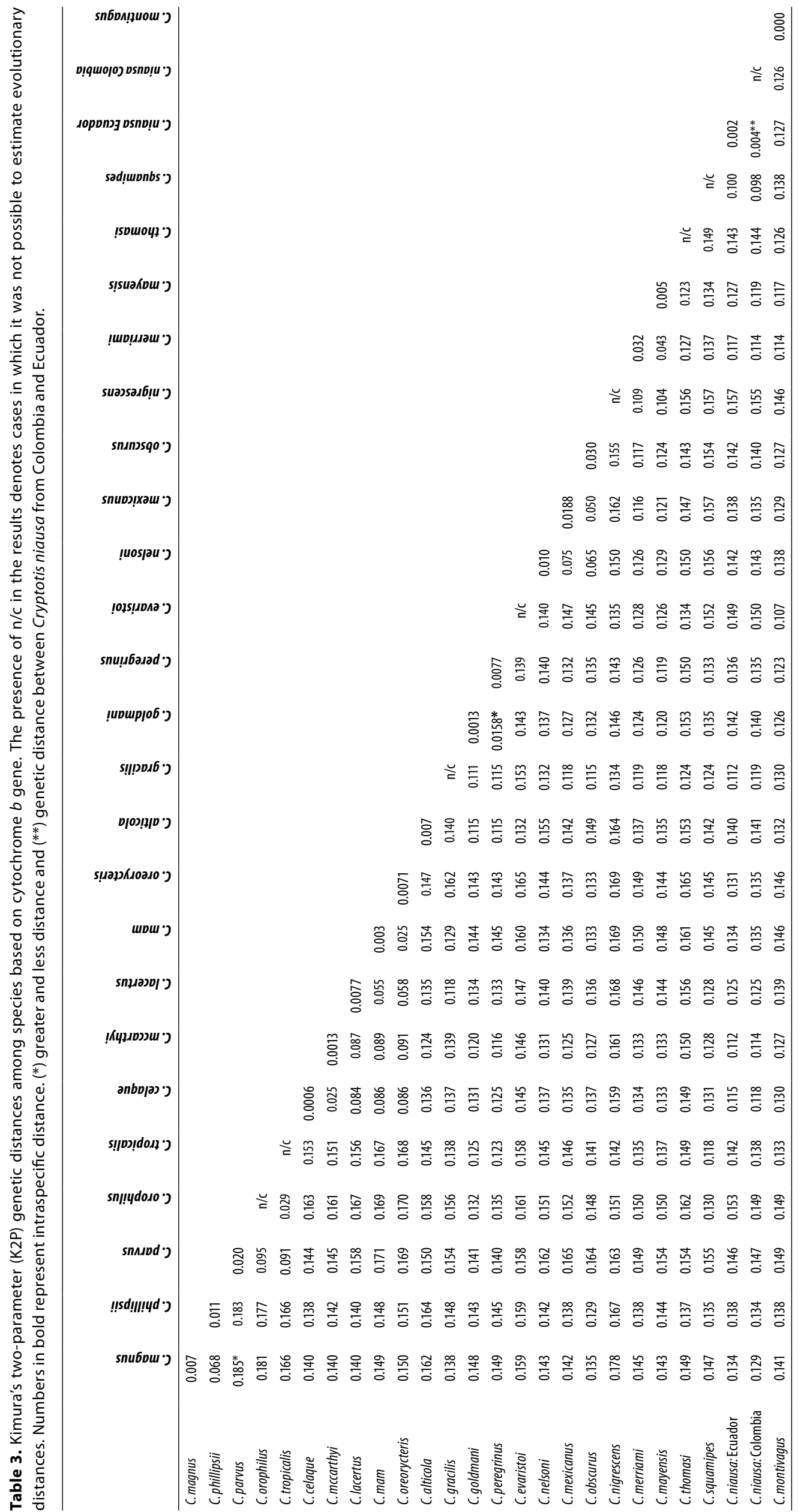


saraña del género Cryptotis Pomel 1848 (Mammalia: Soricomorpha: Soricidae) de Ecuador y estatus taxonómico de Cryptotis equatoris Thomas (1912). Papéis Avulsos de Zoologia 54: 403418. https://doi.org/10.1590/0031-1049.2014.54.28.

Noguera-Urbano EA (2016) Mastozoología en Nariño y algunos comentarios sobre la biogeografía de la región. Revista de Ciencias $7: 1-18$.

Noguera-Urbano EA, Ramírez-Chaves HE, Torres-Martínez MM (2016) Análisis geográfico y conservación del zorro andino ( $L y$ calopex culpaeus: Mammalia) en Colombia. Iheringia, Série Zoologia 106: e2016014. https://doi.org/10.1590/1678-4766e2016014

Noguera-Urbano EA, Colmenares-Pinzón JE, Villota J, RodríguezBolaños A, Ramírez-Chaves HE (2019) Shrews (Cryptotis) of Colombia: What do we know about them? Therya 10: 131-147. https://doi.org/10.12933/therya-19-760

Olson DM, Dinerstein E, Wikramanayake ED, Burgess ND, Powell GVN, Underwood EC, D'Amico JA, Strand HE, Morrison JC, Loucks CJ, Allnutt TF, Lamoreux JF, Ricketts TH, Itoua I, Wettengel WW, Kura Y, Hedao P, Kassem K (2001) Terrestrial ecoregions of the world: a new global map of terrestrial ecoregions provides an innovative tool for conserving biodiversity. BioScience 51: 933-938. https://doi.org/10.1641/0006-3568(2001)051[0933:te otwa]2.0.co;2

Quiroga-Carmona M, DoNascimiento C (2016) A new species of small-eared shrew of the genus Cryptotis Pomel, 1848 (Mammalia, Eulipotyphla, Soricidae) from the easternmost mountains of the Venezuelan Andes. Mammalian Biology 81: 494-505. https:// doi.org/10.1016/j.mambio.2016.04.002

Rambaut A, Drummond A (2010) FigTree v1. 3.1. Institute of Evolutionary Biology, University of Edinburgh, UK. http://tree.bio. ed.ac.uk/software/figtree/

Ramírez-Chaves HE, Noguera-Urbano EA (2011) Lista preliminar de los mamíferos (Mammalia: Theria) del Departamento de Nariño - Colombia. Biota Colombiana 11: 115-138. https://doi. org/10.1016/j.mambio.2016.04.002

Roach N, Naylor L (2020) Cryptosis niausia (amended version of 2019 assessment). The IUCN Red List of Threatened Species 2020: e.T96829156A164136736. https://doi.org/10.2305/iucn.uk.2020-1. rlts.t96829156a164136736.en. Accessed on: 2021-5-03.

Thompson JD, Gibson TJ, Plewniak F, Jeanmougin F, Higgins DG (1997) The CLUSTAL_X windows interface: flexible strategies for multiple sequence alignment aided by quality analysis tools. Nucleic acids research 25: 4876-4882. https://doi.org/10.1093/ $\operatorname{nar} / 25.24 .4876$

Voss RS (2003) A new species of Thomasomys (Rodentia: Muridae) from eastern Ecuador, with remarks on mammalian diversity and biogeography in the Cordillera Oriental. American Museum Novitates 3421: 1-47. https://doi.org/10.1206/00030082(2003)421<0001:ansotr $>2.0$. co; 2

Woodman N, Péfaur J (2008) Order Soricomorpha Gregory. In: Gardner AL (Ed.) Mammals of South America, volume 1. Marsupials, xenarthrans, shrews, and bats. University of Chicago Press, Chicago, USA, 177-187.

Zhang J, Kapli P, Pavlidis P, Stamatakis A (2013) A general species delimitation method with applications to phylogenetic placements. Bioinformatics 29: 2869-2876. https://oi.org/10.1093/ bioinformatics/btt499

Zeballos H, Pino K, Medina CE, Pari A, Chávez D, Tinoco N, Ceballos C (2018) A new species of small-eared shrew of the genus Cryptotis (Mammalia, Eulipotyphla, Soricidae) from the northernmost Peruvian Andes. Zootaxa 4377: 51-73. https://doi. org/10.1016/j.mambio.2016.04.002

\section{Supplemental files}

Figure S1. Genetic tree constructed using maximum probability PTPs and nodes of the 112 species using 1,440 positions for the cytochrome $b$ gene.

Table A1. List of sequences included in the phylogenetic and distance analyzes. 